Brit. F. vener. Dis. (1969), 45, 126.

\title{
FALSE POSITIVE REACTIONS TO THE REITER PROTEIN COMPLEMENT-FIXATION (RPCF) TEST*
}

\author{
BY
}

\author{
L. FÖRSTRÖM, A. LASSUS, AND E. J. JOKINEN \\ Department of Dermatology and Venereology, University Central Hospital, Helsinki, Finland
}

As previously reported (Pillot, Betz, Colombani, and Ripault, 1965), the Reiter Protein ComplementFixation (RPCF) test gives false positive reactions in 0.05 to 0.5 per cent. of cases as a consequence of an antipolysaccharide antibody present in the serum of some individuals. Since, during the years 1960-67, we have performed this test routinely on every patient hospitalized in our clinic, we have found it essential to estimate the incidence of false positive RPCF reactions and to classify them with regard to duration. At the same time, it was possible to compare the RPCF result with clinical data, in the hope that correlations with the serological findings would be revealed.

\section{Material and Methods}

During the years 1960-67, 22,769 patients were hospitalized in our clinic. Blood samples for serological tests for syphilis were taken from every patient. These tests were the old-type Wassermann and the Wassermann sensitized with cholesterol, the Kahn, VDRL slide, Kolmer, and RPCF tests. If the patient's serum was positive in one or several tests, new serum samples were taken. When the serum remained positive on retesting, the TPI test was performed and, in the majority of cases, the FTA-ABS test also.

The Wassermann tests, as well as the Kahn, VDRL slide, and Kolmer tests were performed as previously described (Förström, 1967). The RPCF test was carried out according to the technique described in the 1959 Manual of Serologic Tests for Syphilis (US PHS, 1959), i.e. as a semi-quantitative one-fifth volume Kolmer test with Reiter protein as antigen and using two exact units of complement. The antigen was obtained from the National Institute of Public Health, Utrecht, Holland.

The technique employed in the TPI test has been described by Nelson and co-workers (Nelson and Mayer, 1949; Nelson and Diesendruck, 1951). The FTA-ABS test was performed according to the provisional technique published in 1965 from the Venereal Disease Research Laboratory (USPHS, 1965).

$\star$ Received for publication June 5, 1968.
During the period, 721 cases were diagnosed as syphilis on the basis of clinical findings or positive TPI results or both and were excluded from the study.

A single positive reaction in the RPCF test was interpreted as a laboratory error if negative results were later obtained with new serum samples from the same patient, provided that the lipoidal tests (STS) were negative and the patient had no history or clinical evidence of syphilis.

The positive result in the RPCF test was considered to be probably a false positive in the following circumstances:

(a) The test gave a positive result on at least two serum samples, the TPI and/or FTA-ABS test was negative, and neither the history nor the clinical examination revealed evidence of syphilis.

(b) The RPCF test was only once positive, but the positive result was accompanied by positivity in one or several lipoidal tests: the TPI and/or FTA-ABS tests were negative, and the history and clinical examination of the patient revealed no evidence of syphilis.

In six cases neither the TPI nor the FTA-ABS test could be performed. However, a rapid reversal to RPCFnegativity in four of these cases argued in favour of the non-specific character of the reaction. In the remaining two cases additional testing could not be performed because of the death of the patient.

\section{Results}

According to the criteria mentioned above, 79 patients ( 37 males, 42 females, average age 50 years) out of 22,048 were interpreted as probable false positive reactors in the RPCF test. This represents 0.36 per cent. of the whole series. In 34 of these cases the RPCF test was strongly positive (readings $3+$ and $4+$ ).

In 49 cases the false positive reaction was acute ( $<6$ months' duration) and in 23 cases chronic ( $\geqq 6$ months' duration). In seven cases the type of the reaction could not be determined because the follow-up period was too short. Sera from 43 patients were also positive in one or several lipoidal tests. 
As seen in Table I, TPI and/or FTA-ABS tests were performed in all 23 chronic cases as well as in 45 of the 49 acute cases. In 54 patients, both TPI and FTA-ABS had been carried out. As these patients fulfil the modern criteria for biological false positive (BFP) reactors, the clinical diagnoses and serological findings are presented in Table II. Additionally, sera from 35 of the 54 patients gave positive results in one or several lipoidal tests. The group described as "various dermatoses" included one case each of discoid lupus erythematosus, Waldenström's purpura, myeloma, dermatomyositis, mycosis fungoides, sarcoidosis, pemphigoid, acrodermatitis atrophicans (Herxheimer), erythema exudativum multiforme, exanthema medicamentosum, pityriasis rubra pilaris, pyoderma, and moniliasis.

Eight of the patients with acute false positive reactions to the RPCF test had systemic lupus erythematosus. Of the remaining 26 cases seventeen had evidence of acute infections, including bronchopneumonia, tonsillitis, sinusitis, pyelitis, or skin infections such as pyoderma, furunculosis, moniliasis, and herpes. In addition, six had an increased antistreptolysin and/or antistaphylolysin titre. Three of the patients with chronic false positive reactions had diffuse connective tissue diseases, and of the remaining fifteen patients eleven had infections of the same type as in the transient reactions and three additional patients had an increased antistreptolysin and/or antistaphylolysin titre.
It may be mentioned that in the patients with SLE the positive result in the RPCF test often alternated with negative and anticomplementary results, whereas the lipoidal tests were consistently positive.

At least eleven of the patients died during the follow-up period.

\section{Discussion}

Previously (Bekker, de Bruijn, and Miller, 1966), an incidence of approximately 1 per cent. of nonspecific RPCF reactions has been reported. In our series the corresponding number was 0.36 per cent. The difference may perhaps be explained by the fact that in the former study undiluted patient serum and only 1.5 exact units of complement were used, which makes the test considerably more sensitive. Some of our patients may have had syphilis, because a single negative TPI test does not exclude syphilis (Tuffanelli, Wuepper, Bradford, and Wood, 1967). In fact, not even the performance of both TPI and FTA-ABS tests can with certainty exclude syphilis (Lassus, 1968). The true incidence of BFP reactions in the RPCF test may therefore be somewhat lower than the percentage found by us. On the other hand, some of the cases with a single positive result in the RPCF test, which we have interpreted as laboratory errors, may, in fact, have been BFP-reactors or syphilitics. We consider it safer, however, to exclude these cases from our series.

TABLE I

TREPONEMAL VERIFICATION TESTS PERFORMED IN 79 CASES WITH PROBABLE FALSE POSITIVE REACTIONS TO THE RPCF TEST

\begin{tabular}{|c|c|c|c|c|c|c|c|c|c|}
\hline & & & & & $\begin{array}{l}\text { TPI and } \\
\text { FTA-ABS }\end{array}$ & $\begin{array}{l}\text { TPI } \\
\text { Only }\end{array}$ & $\begin{array}{c}\text { FTA-ABS } \\
\text { Only }\end{array}$ & $\begin{array}{c}\text { Neither TPI } \\
\text { nor FTA-ABS }\end{array}$ & Total \\
\hline $\begin{array}{l}\text { Acute } . . \\
\text { Chronic . } \\
\text { Not classified }\end{array}$ & $\begin{array}{l}\cdots \\
\cdots \\
\cdots\end{array}$ & $\begin{array}{l}\cdots \\
\cdots \\
\cdots\end{array}$ & $\begin{array}{l}\cdots \\
\cdots \\
\cdots\end{array}$ & $\begin{array}{l}\cdots \\
\cdots \\
\cdots\end{array}$ & $\begin{array}{r}34 \\
18 \\
2\end{array}$ & $\begin{array}{l}8 \\
4 \\
3\end{array}$ & $\begin{array}{r}3 \\
1 \\
-\end{array}$ & $\frac{4}{2}$ & $\begin{array}{r}49 \\
23 \\
7\end{array}$ \\
\hline Total & . & $\ldots$ & $\ldots$ & $\ldots$ & 54 & 15 & 4 & 6 & 79 \\
\hline
\end{tabular}

TABLE II

CLINICAL DIAGNOSES AND SEROLOGICAL FINDINGS IN 54 CASES WITH FALSE POSITIVE REACTIONS TO THE RPCF TEST

\begin{tabular}{|c|c|c|c|c|c|c|c|c|c|c|}
\hline \multirow{2}{*}{\multicolumn{4}{|c|}{ Clinical Diagnosis }} & \multicolumn{2}{|c|}{ Acute } & \multicolumn{2}{|c|}{ Chronic } & \multicolumn{2}{|c|}{ Not classified } & \multirow{2}{*}{ Total } \\
\hline & & & & \multirow[b]{2}{*}{$\begin{array}{c}\text { STS }+ \\
7 \\
5 \\
3 \\
2 \\
1 \\
1 \\
1 \\
1 \\
4\end{array}$} & STS - & $\begin{array}{c}\text { STS + } \\
2 \\
1 \\
1\end{array}$ & $\frac{\text { STS - }}{-}$ & $\frac{\text { STS }+}{-}$ & $\frac{\text { STS - }}{-}$ & \\
\hline $\begin{array}{l}\text { Systemic lu } \\
\text { Eczema } \\
\text { Psoriasis } \\
\text { Leg ulcers } \\
\text { Atopy } \\
\text { Urticaria } \\
\text { Rheumatoic } \\
\text { Herpes sim } \\
\text { Various der }\end{array}$ & 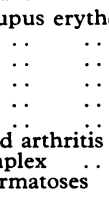 & $\begin{array}{l}\text { atosus } \\
\ldots \\
\ldots \\
\ldots \\
\ldots \\
\ldots \\
\ldots\end{array}$ & $\begin{array}{l}\ldots \\
\ldots \\
\cdots \\
\ldots \\
\cdots \\
\ldots\end{array}$ & & $\begin{array}{l}1 \\
2 \\
3 \\
1 \\
1 \\
-\end{array}$ & $\begin{array}{l}2 \\
1 \\
- \\
- \\
\end{array}$ & $\begin{array}{l}-1 \\
2 \\
1 \\
1 \\
1 \\
1 \\
3\end{array}$ & $\begin{array}{l}= \\
= \\
=\end{array}$ & $\begin{array}{l}= \\
= \\
z \\
z\end{array}$ & $\begin{array}{r}10 \\
9 \\
9 \\
4 \\
3 \\
2 \\
2 \\
2 \\
13\end{array}$ \\
\hline Tota & $\cdots$ & $\ldots$ & $\ldots$ & 25 & 9 & 8 & 10 & 2 & 一 & 54 \\
\hline
\end{tabular}


Our study indicates that true repeatable positive results do occur non-specifically in the RPCF test. These positive results are usually transient, but in some cases persist over long periods. Several of the patients had systemic lupus erythematosus or other connective tissue disorders, and in the majority of them the lipoidal tests were positive as well. It is surprising that in most of these patients the RPCF positivity was acute or transient, whereas positivity in the lipoidal tests was, as a rule, a persistent finding. The majority of the remaining patients, of whom more than half had positive lipoidal tests, had evidence of bacterial or viral infections, whom perhaps may account for the non-specific result. It would in this respect be most interesting to know the clinical findings in the cases presented by earlier investigators.

When used for screening, obviously not only the lipoidal tests but also a treponemal test like the RPCF test may indicate, besides syphilis, diseases of immunological aberration. It has been stated (Neblett, Merriam, Burnham, and Fine, 1964) that in some circumstances serum containing antinuclear antibodies may yield reactive FTA-200 tests, and false positive RPCF results have also been associated with an autoimmune process (Stevens, Boylan, and Memoli, 1967). Likewise, it has been reported (Fife, 1964) that non-specific FTA reactions can be associated with increased macroglobulin levels. This is not surprising, since some of the antibodies detected in the RPCF test and in the FTA tests without absorption with Reiter treponemes are probably the same.

\section{Summary}

The authors studied a series of 22,048 patients, from which 721 syphilitics had been excluded, by means of the RPCF test. After exclusion of cases with positive results on a single occasion, which were probably attributable to technical errors, probable false positive reactions to this test were found in sera from 79 patients, representing 0.36 per cent. of the whole series. In 49 cases the reaction was acute ( $<6$ months' duration), and in 23 cases chronic ( $\geqq 6$ months' duration). Seven patients could not be classified, since the follow-up period was too short. In a total of 43 cases positive results were also obtained in some of the five lipoidal tests used. Ten of the 54 patients on whom both TPI and FTA-ABS tests were performed had systemic lupus erythematosus and two had rheumatoid arthritis. In most of these cases the reaction to the RPCF test was acute or transient, whereas the lipoidal tests showed persistent positivity. Of the remaining cases the majority had evidence of some infectious disease.

\section{REFERENCES}

BekKer, J. H., BruijN, J. H. DE, and MILler, J. N. (1966). Brit. F. vener. Dis., 42, 42.

FIFE, E. H., Jr. (1964). "Influence of macroglobulins on the specificity of fluorescent treponemal antibody (FTA) test for syphilis", in "Proc. World Forum on Syphilis and Other Treponematoses, Washington, D.C., 1962", p. 254. USPHS Publ. No. 997. Washington, D.C.

FöRSTRÖM, L. (1967). Acta derm.-venereol. (Stockh.), 47, Suppl. 59 (Dissert.), "Reiter Protein Complement-Fixation (RPCF) Test as a Serological Test for Syphilis", p. 29.

LAssus, A. (1968). Ibid., 48, Suppl. 60 (Dissert.), "Treponemal and Lipoidal Tests in Old Treated Syphilis".

Neblett, T. R., Merriam, L. R., Burnham, T. K., and FINE, G. (1964). F. invest. Derm., 43, 439.

Nelson, R. A., Jr., and DiesENDRUCK, J. A. (1951). F. Immunol., 66, 667.

- and MAYER, M. M. (1949). F. exp. Med., 89, 369.

Pillot, J., Betz, A., Colombani, J., and Ripault, J. (1965). Brit. f. vener. Dis., 41, 170.

Stevens, R. W., Boylan, J., and MEMOLI, A. J. (1967). Amer. F. clin. Path., 47, 408.

TUFFanelLI, D. L., WUEPPER, K. D., BRADFORD, L. L., and Wood, R. M. (1967). New Engl. f. Med., 276, 258.

U.S. Department of Health, Education, and Welfare (1959), "Serologic Tests for Syphilis, 1959 Manual". USPHS Publication No. 411. U.S. Government Printing Office, Washington, D.C.

- (1965), "Provisional Technique for the Fluorescent Treponemal Antibody-Absorption (FTA-ABS) Test", p. 9. Communicable Disease Center, Venereal Disease Research Laboratory, USPHS, Atlanta, Ga.

Les réactions pseudo-positives au test de fixation du complément de la protéine de Reiter (R P C F)

\section{RÉSUMÉ}

Les auteurs ont étudié une série de 22.048 malades, desquels 721 syphilis cliniques avaient été exclus, au moyen du test R C P F. Après l'exclusion des cas donnant des résultats positifs à un seul test, ce qui était probablement attribuable à des erreurs techniques, des réactions pseudo-positives à ce test ont été constatées chez 79 malades, représentant 0,36 pour cent de toute la série. Dans 49 cas la réaction était aiguë (d'une durée de moins de six mois), et dans 23 cas chroniques (d'une durée $\geqslant$ six mois). Sept malades n'avaient pu être classés, parce que la période de surveillance avait été trop courte. Dans 43 cas des résultats positifs avaient été aussi obtenus dans certains des cinq tests lipoïdiques employés. Dix des 54 malades qui avaient subi les deux tests TPI et FTA-ABS étaient atteints de lupus érythémateux et deux étaient atteints de polyarthrite rhumatoïde. Dans la plupart de ces cas la positivité au test RPCF était aiguë ou transitoire tandis que les tests lipoïdiques montraient une positivité persistante. La majorité des cas restants témoignait de la présence de quelque maladie infectieuse. 